\title{
Arawakan Language
}

National Cancer Institute

\section{Source}

National Cancer Institute. Arawakan Language. NCI Thesaurus. Code C161912.

A language family that developed among ancient indigenous peoples in South America. 